\title{
Role of Testosterone Replacement Therapy on Plasma Ghrelin Level before and after Orchiectomy in Male Albino Rats
}

\author{
Sahar A El-Sawy* and Amel A. Hashish** \\ Departments of Physiology* and General Surgery** \\ Tanta faculty of Medicine
}

\begin{abstract}
The aim of the present study is to investigate whether testosterone replacement therapy play a role on plasma ghrelin level before and after orchiectomy in male albino rats. Four groups of animals were studied, control group, control group received testosterone propionate (T.P) $300 \mu \mathrm{g} / \mathrm{Kg}$ subcutaneously (s.c) daily for 4 weeks, orchiectomized group and lastly orchiectomized group receiving T.P by the same regimen as group two. Blood samples were taken at the end of the experimental period for carrying out the hormonal investigations; also body weight was measured from all studied animals. The results of this work showed that subcutaneous administration of T.P to sham operated and orchiectomy rats produces significant decrease in FSH and LH, however it produces significant increase in total testosterone, free testosterone, ghrelin, insulin-like growth factor-I (IGF-I) and total body weight when these results compared to group one and three respectively. Conclusions: We can conclude that plasma ghrelin level significantly increase after testosterone supplementation in both sham operated and orchiectomy rats, also there are +ve correlation between ghrelin level and testosterone level (both total and free), IGF-1 and body weight \& negative correlation between ghrelin and FSH \& LH.
\end{abstract}

\section{INTRODUCTION}

Ghrelin is a noval polypeptide hormone predominantly synthesized by the stomach and involved in food intake regulation. ${ }^{(1)}$ Ghrelin was identified as an endogenous ligand for an orphan receptor termed GHsecretagogue receptor possessing potent GH releasing activity. ${ }^{(2)}$

Previous studies conducted in healthy children and adolescents revealed that ghrelin levels reach a peak in early post natal life and then gradually decrease during childhood and adolescence. ${ }^{(3)}$
The precise mechanisms underlying these changes have not been fully elucidated. ${ }^{(4)}$

Further studies have suggested that androgen and ghrelin may reciprocally cross-talk, Gonadal tissues have in fact been proposed as a target for ghrelin action based on a higher number of binding sites in both ovary and testis. ${ }^{(5)}$

In addition to this first descriptive evidence that ghrelin might play a role in regulation of reproductive physiology, one study has shown that ghrelin affects the chorionic gonodotropin and cAMP induced 
testosterone secretion in rat testis by inhibiting key enzymes of steroidogenic pathway, ${ }^{(6)}$ Moreover, it has been demonstrated that gonads are not only target tissues for ghrelin, but also relevant sites of ghrelin production, in both testis and ovary, ghrelin is co-expressed with sex hormones in androgen producing cells like leydig and hilus interstitial cells. ${ }^{(7)}$

The hypthalmo-pituitary mechanism by which testosterone promotes $\mathrm{GH}$ secretion and there by elevates insulin-like growth factor-I (IGF-I) concentration in human are unknown. ${ }^{(\mathbf{)}}$

The mechanisms by which sex hormones, particularly androgen may regulate ghrelin expression and secretion are still poorly defined, moreover, it is still undefined whether their regulatory capacity could be influenced by the interference of other hormones and factors. ${ }^{(5)}$

So the aim of the present work is to study the role of testosterone replacement therapy on plasma ghrelin level before and after orchiectomy in male albino rats.

\section{MATERIAL \& METHODS}

45 male albino rats weighing between (250-350 g) were used in this study, they were kept under constant environmental and nutritional conditions through out the experiment. Rats were randomly divided into four groups

Group I: Control animals underwent a sham orchiectomy and received no medications for 4 weeks $(n=8)$.

Group II: Control animals underwent a sham orchiectomy and received testosterone propionate (T.P) 300 $\mu \mathrm{g} / \mathrm{Kg}$ subcutaneously (s.c) daily for 4 weeks. ${ }^{(9)}(\mathrm{n}=10)$

Group III: The animals underwent an orchiectomy at the start of the experimental protocol and received no medications for the length of the protocol 4 weeks $(\mathrm{n}=12)$.

Group IV: The animals underwent a surgical orchiectomy and received s.c (T.P) $300 \mu \mathrm{g} / \mathrm{Kg}$ daily for 4 weeks ( $\mathrm{n}=$ 15).

At the end of experimental periods, blood samples withdrawn into EDTA containing tubes for plasma and serum samples were taken in the morning after an over night fast. Body weight was measured from all studied animals at the end of experimental periods.

Methods:

- Determination of serum level of total and free testosterone by enzyme immunoassay in rat serum. ${ }^{(\mathbf{1 0})}$

- Determination of follicle stimulating hormone (FSH) and luitinizing hormone (LH) concentrations by using enzyme linked immunosorbent assay. ${ }^{\text {(11) }}$

- Insulin-like growth factor-I was determined by enzyme linked immunosorbent assay. ${ }^{(12)}$

Quantitative determination for rat ghrelin:

Plasma levels of ghrelin were assayed using reagent kits and methods provided by Kamiya BioMedical Company. Samples were collected in tubes containing EDTA. $2 \mathrm{Na}(1.25 \mathrm{mg} / \mathrm{ml}$ blood $)$ and aprotinin (500 units $/ \mathrm{ml}$ blood). Plasma ghrelin determined by 2 sites sandwich enzyme linked immunosorbent assay (ELISA), measure the absorbance at $450 \mathrm{~nm}^{\left({ }^{13}\right)}$ 


\section{Surgical procedure:}

Weigh and anesthetize the animal. Bilateral orchiectomy was performed as described by Svensson et al. ${ }^{(14)}$ a small surgical incision was made in the center of the scrotum, each testicle was exposed through the surgical orifice. The ductus deferens and main arteries and veins were isolated and ligated. Subsequently the duct and blood vessels were severed allowing the testicle and epididymis to be removed. The incision was then closed, sutured and swabbed with iodine solution. The sham operation involved the exposure of the testis without excision.

The post operative procedure was implemented by proper antibiotics, finally the rats were housed in separate cages and allowed free access to food and water.

\section{Statistical analysis:}

Data analyses were performed with the soft ware package SPSS program version 11, the results of continuous variables are presented as mean \pm SD and statistically analyzed using the unpaired "t" test.

Pearson's and spear man's correlation were applied to examine the relationships among ghrelin and the other studied parameters.

\section{RESULTS}

Five rats died during the experimental period two from group III and three from group IV

Subcutaneous administration of T.P to sham operated rats produces significant increase in serum level of total $\mathrm{T}$ and free $\mathrm{T}$ when compared to normal control $(\mathrm{P}<0.05)$ (table1 \& fig $1,2)$, also it produces significant reduction in FSH and LH $(\mathrm{P}<0.05)$, when compared with control (table $1 \&$ fig 3,4).

As regard the effect of T.P supplementation on plasma ghrelin level it produces significant increase $(\mathrm{P}<0.05)$, this values corresponding to significant increase in IGF-1 $(\mathrm{P}<0.05)$. Table (1) \& Fig $(5,6)$ as compared to control values.

After orchiectomy the serum level of total $\mathrm{T}$ and free $\mathrm{T}$ show significant decrease $(\mathrm{P}<0.05)$, but orchiectomy produces significant increase in serum level FSH and LH $(\mathrm{P}<0.05)$ when compared with sham operated rats (table 1\& fig 1, 2, 3, 4). Also orchiectomy produces significant reduction in plasma level ghrelin $(\mathrm{P}<0.05)$ and IGF-I $(\mathrm{P}<0.05)$ when compared with sham operated rats (table $1 \&$ fig 5,6)

T.P supplementation to orchiectomized rats produce significant increase in total $\mathrm{T}$ and free $\mathrm{T}$ when compared to orchiectomy group, but it produces significant decrease in FSH and $\mathrm{LH} \quad(\mathrm{P}<0.05)$ \{table1 \& fig 1,2,3,4\}.

Ghrelin level was significantly higher after T.P supplementation, also this corresponding with significant increase in IGF-I $(\mathrm{P}<0.05)$ when compared with orchiectomy group (table 1 \& fig 5,6).

As regards the effect of T.P supplementation in sham operated and orchiectomy in rats it produces significant weight gain in both groups $(\mathrm{P}<0.05)$ when compared the results with either sham operated orchiectomy or orchiectomy respectively (table1 \& fig7).

There are $+v e$ correlation between ghrelin level and testosterone level (both total and free), IGF-1 and body weight (fig $8,9,12,13$ ) \& negative correlation between ghrelin and FSH \& L H (fig 10, 11). 
Table 1: Effect of T.P supplementation $(300 \mu \mathrm{g} / \mathrm{Kg})$ before and after orchiectomy on hormonal level and body weight in male albino rats (values are mean \pm SD)

\begin{tabular}{|c|c|c|c|c|c|c|c|c|c|}
\hline Groups & No. & \multicolumn{2}{|c|}{$\begin{array}{c}\text { Total } \\
\text { testosterone } \\
\text { ng/ml }\end{array}$} & $\begin{array}{c}\text { Free } \\
\text { testosterone } \\
\text { ng/ml } \\
\end{array}$ & $\begin{array}{c}\text { FSH } \\
\mu \mathrm{IU} / \mathrm{ml}\end{array}$ & $\underset{\mu I U / m l}{\text { LH }}$ & $\begin{array}{l}\text { IGF-1 } \\
\mathrm{ng} / \mathrm{ml}\end{array}$ & $\begin{array}{c}\text { Ghrelin } \\
\text { Pg/ml }\end{array}$ & $\begin{array}{l}\text { Total body } \\
\text { weight (g) }\end{array}$ \\
\hline $\begin{array}{l}\text { GpI } \\
\text { Sham operated (control) }\end{array}$ & 8 & \multicolumn{2}{|c|}{$\begin{array}{c}1.9 \\
\pm 0.1\end{array}$} & $\begin{array}{c}0.12 \\
\pm 0.02\end{array}$ & $\begin{array}{c}2.39 \\
\pm 0.16\end{array}$ & $\begin{array}{c}2.55 \\
\pm 0.32\end{array}$ & $\begin{array}{l}44.65 \\
\pm 2.98\end{array}$ & $\begin{array}{l}127.35 \\
\pm 5.78\end{array}$ & $\begin{array}{c}294.5 \\
\pm 10.31\end{array}$ \\
\hline $\begin{array}{l}\text { GpII } \\
\text { Sham operated+T.P }\end{array}$ & 10 & \multicolumn{2}{|c|}{$\begin{array}{c}2.30 \\
\pm 0.35\end{array}$} & $\begin{array}{c}0.16 \\
\pm 0.02\end{array}$ & $\begin{array}{c}1.49 \\
\pm 0.33\end{array}$ & $\begin{array}{c}1.39 \\
\pm 0.47\end{array}$ & $\begin{array}{r}51.45 \\
\pm 4.92 \\
\end{array}$ & $\begin{array}{l}191.07 \\
\pm 34.07 \\
\end{array}$ & $\begin{array}{c}314.8 \\
\pm 10.11 \\
\end{array}$ \\
\hline & & $t_{1}$ & $\begin{array}{c}3.64 \\
*\end{array}$ & 4. $44^{*}$ & $6.92 *$ & $6.11^{*}$ & $3.62 *$ & $5.53 *$ & $4.19^{*}$ \\
\hline $\begin{array}{l}\text { GpIII } \\
\text { Orchiectomy }\end{array}$ & 10 & \multicolumn{2}{|c|}{$\begin{array}{c}1.18 \\
\pm 0.23\end{array}$} & $\begin{array}{c}0.08 \\
\pm 0.02\end{array}$ & $\begin{array}{c}3.61 \\
\pm 0.41\end{array}$ & $\begin{array}{c}3.19 \\
\pm 0.19\end{array}$ & $\begin{array}{c}34.12 \\
\pm 2.69\end{array}$ & $\begin{array}{c}75.05 \\
\pm 16.13\end{array}$ & $\begin{array}{c}254.9 \\
\pm 14.81\end{array}$ \\
\hline & & $t_{2}$ & $\begin{array}{c}9.00 \\
*\end{array}$ & $4.00 *$ & $8.71 *$ & $4.92 *$ & $7.8^{*}$ & $9.53 *$ & $6.68 *$ \\
\hline \multirow[t]{2}{*}{$\begin{array}{l}\text { GpIV } \\
\text { Orchiectomy +T.P }\end{array}$} & 12 & \multicolumn{2}{|c|}{$\begin{array}{c}1.69 \\
\pm 0.21\end{array}$} & $\begin{array}{c}0.11 \\
\pm 0.02\end{array}$ & $\begin{array}{c}2.48 \\
\pm 0.07\end{array}$ & $\begin{array}{c}2.65 \\
\pm 0.12\end{array}$ & $\begin{array}{r}40.68 \\
\pm 0.55\end{array}$ & $\begin{array}{c}121.2 \\
\pm 2.70\end{array}$ & $\begin{array}{c}273 \\
\pm 9.32 \\
\end{array}$ \\
\hline & & $\mathbf{t}_{3}$ & $\begin{array}{c}5.67 \\
*\end{array}$ & $5.00 *$ & $8.69^{*}$ & $7.71^{*}$ & $7.63^{*}$ & $8.92 *$ & $3.35 *$ \\
\hline
\end{tabular}

* Denotes signifiant $(\mathrm{P}<0.05)$.

(T.P) $=$ Testosterone propionate

$$
\mathbf{t}_{\mathbf{1}}=\text { Gp II vs GpI } \quad \mathbf{t}_{\mathbf{2}}=\text { Gp III vs GpI } \quad \mathbf{t}_{\mathbf{3}}=\text { Gp IV vs Gp III }
$$




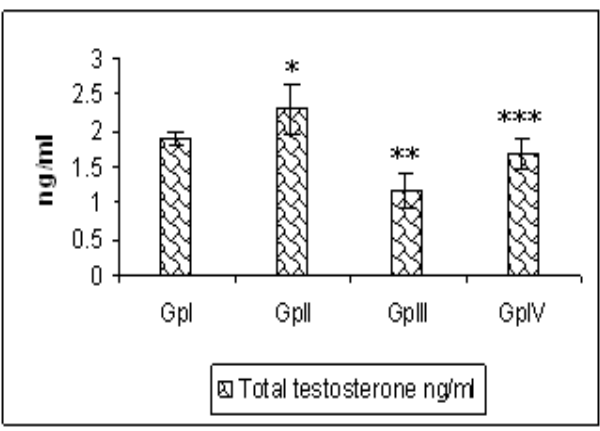

Fig (1) Total testosterone levels in all studied groups *GpII vs GpI **GpIII vs GpI ***GpIV vs GpIII

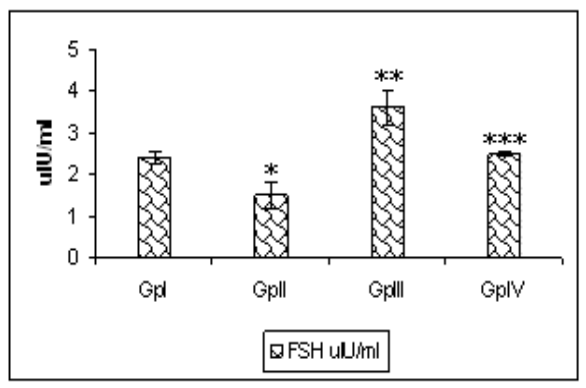

Fig (3) FSH levels in all studied groups *GpII vs GpI **GpIII vs GpI ***GpIV vs GpIII

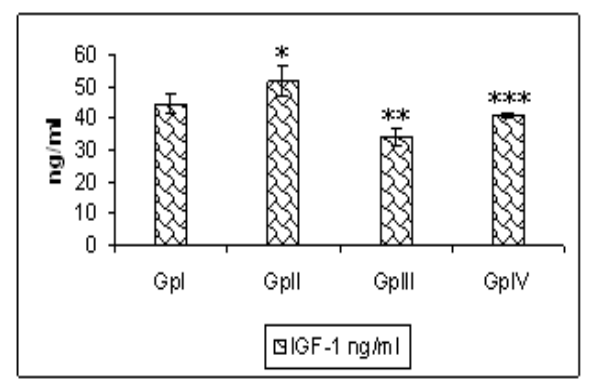

Fig (5) IGF-1 level in all studied groups ${ }^{*} G$ II vs GpI **GpIII vs GpI ${ }^{* * *}$ GpIV vs GPIII

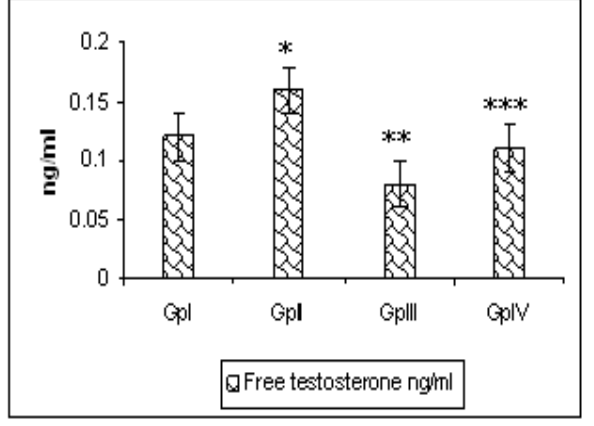

Fig (2) Free testosterone levels in all studied groups*GpII vs GpI **GpIII vs GpI ***GpIV vs GpIII

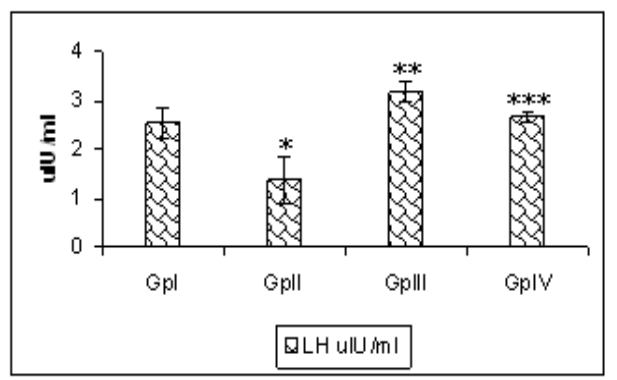

Fig (4) LH levels in all studied groups *GpII vs GpI **GpIII vs GpI ***GpIV vs GPIII

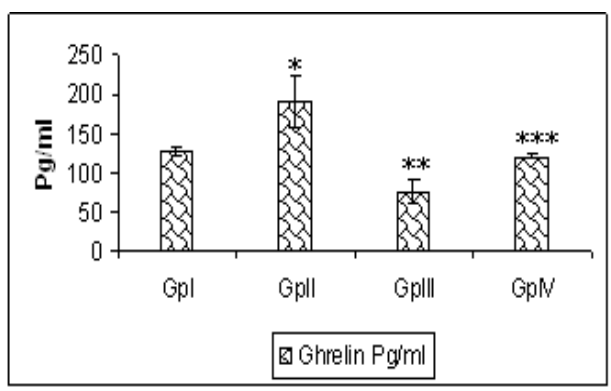

Fig (6) Ghrelin levels in all studied groups *GpII vs GpI **GpIII vs GpI ***GpIV vs GpIII 


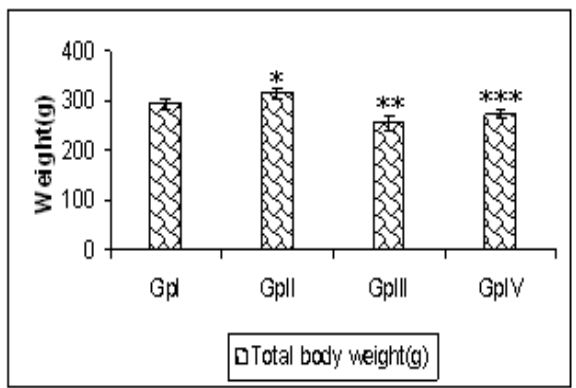

Fig (7) TBW level in all studied groups*GpII vs GpI **GpIII vs GpI ***GpIV vs GpIII

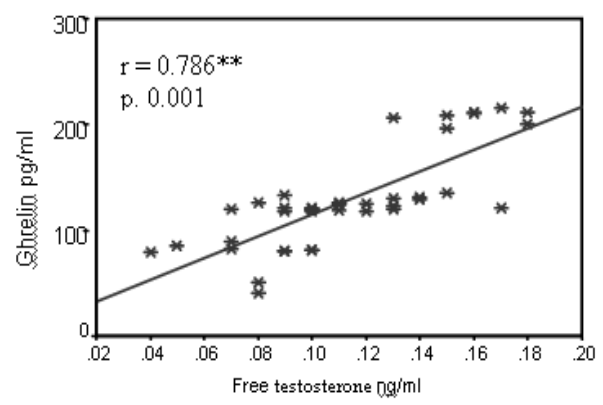

Fig (9) Correlation between ghrelin and free testosterone among the studied groups

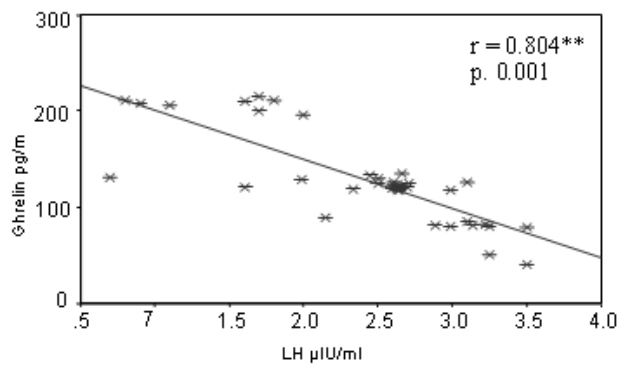

Fig (11) Correlation between ghrelin and $\mathrm{LH}$ among the studied groups

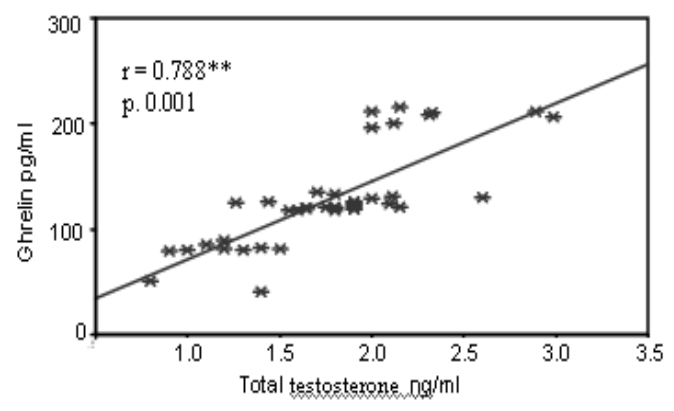

Fig (8) Correlation between ghrelin and total testosterone among the studied groups

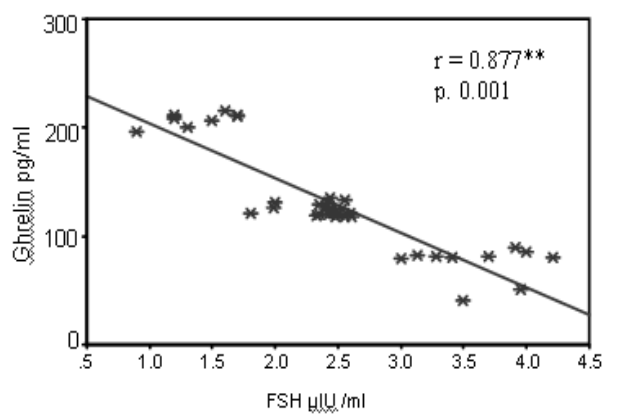

Fig (10) Correlation between ghrelin and FSH among the studied groups

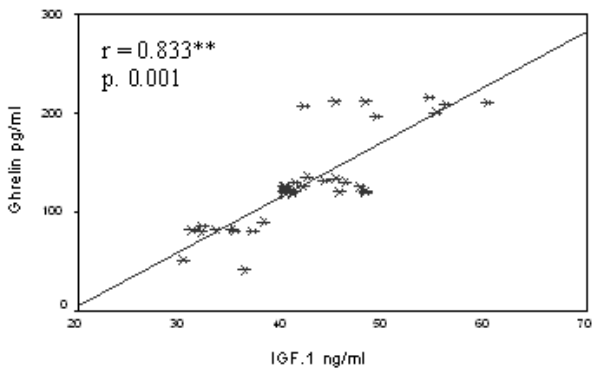

Fig (12) Correlation between ghrelin and IGF-1 among the studied groups 


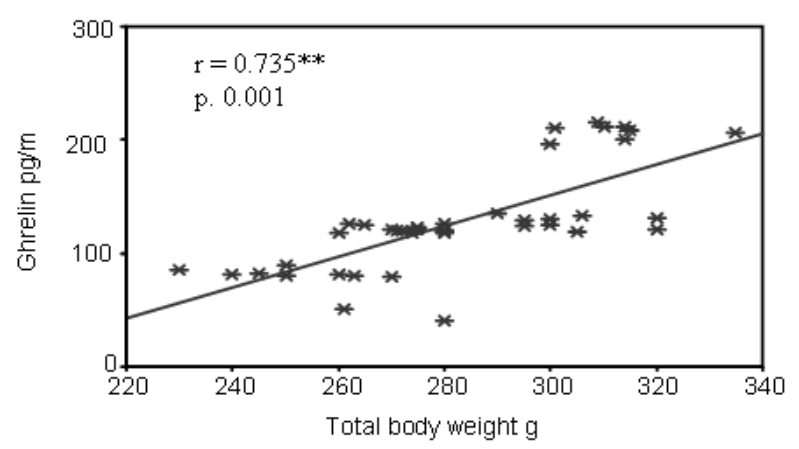

Fig (13) Correlation between ghrelin and total body weight among the studied groups

\section{DISCUSSION}

In our present study, we have attempted to examine the possible role and mechanism of action of testosterone replacement therapy on plasma ghrelin level before and after orchiectomy in male albino rats. It is clear from the present results that s.c administration of T.P to sham operated and orchiectomy rats produces significant decrease in FSH and $\mathrm{LH}$, however it produces significant increase in total testosterone, free testosterone, ghrelin, IGF-I and total body weight.

Our results can be partly explained by previous research finding, that androgen play an important regulatory role regarding ghrelin secretion or catabolism. Also the relationship between androgen and ghrelin is positive in male individuals. ${ }^{(15)}$

Tena Sempere. ${ }^{(6)}$ proved a good link between energy homeostasis and fertility, and the clear cut reproductive effect of other regulator of energy homeostasis and growth, the potential role of ghrelin in the control of gonadal function has so far received little attention ${ }^{(\mathbf{1 6})}$.

Pagotto et al. ${ }^{(16)}$ demonstrated that total and free testosterone and plasma ghrelin levels were significantly lower in hypogondal men. ${ }^{(17)}$

Ishikawa et al. ${ }^{(17)}$ reported that ghrelin levels were positively correlated with both total and free testosterone concentration. ${ }^{(\mathbf{1 8})}$

$\quad$ Also Le benthal et al. ${ }^{(18)}$
suggested that testosterone
replacement therapy significantly
increase plasma ghrelin. ${ }^{(19)}$

The normalization of the androgen status rather than an unnatural increase or decrease may recover suppressed ghrelin secretion and may possibly reestablish a balanced energy homeostasis. (20)

The mechanism by which testosterone level alter ghrelin concentration may be explained by that testosterone may act directly on both peptide expression and synthesis as well as on ghrelin metabolic pathway. ${ }^{(16)}$ 
Another explanation is that testosterone substitution normalize serum leptin secretion in hypogonadal patient, we can therefore hypothesize that leptin normalization may be involved in elevation of ghrelin levels. ${ }^{(21)}$

Testosterone supplementation significantly increase in body weight in sham operated and orchiectomy rats (tab1 \& fig7).

Testosterone induces an increase in free fatty acid (FFA) release from the visceral fat depot. ${ }^{(22)}$

The link between FFA and ghrelin has been demonstrated by Broglio et al. ${ }^{\text {(23) }}$ who reported that FFA infusion increase the ability of ghrelin to induce growth hormone $(\mathrm{GH})$ secretion from the pituitary, ${ }^{(23)}$

Additionally it has been shown that a fat rich diet known to increase circulating FFA, was able to increase circulating ghrelin levels in experimental rats. ${ }^{(24)}$

Barreiro et al. ${ }^{(5)}$ observed that ghrelin peptide was selectively detected in rat leydig cells at advanced stages of maturation, (5) also TenaSemper et al. ${ }^{(6)}$ demonstrated that ghrelin expression became undetectable after selective elimination of mature leydig cells by administration of cytotoxic compound. ${ }^{(6)}$

The significant decrease in FSH and LH observed in this work in sham operated and orchiectomy rats treated by T.P could be explained by increase in ghrelin level in this work (table1) may participate in the regulation of gonadotropin secretion. ${ }^{(25)}$

Zigman et al., proposed that the role of ghrelin as a peripheral signal for energy insufficiency and its role in reproductive effect, it appears feasible that circulating ghrelin might contribute to functional control of the reproductive axis and its integration with energy balance. ${ }^{\text {(26) }}$

Ghrelin inhibit pulsatile LH secretion in overiectomized female rats Furuta et al. ${ }^{(27)}$

In vivo ghrelin inhibit $\mathrm{GnRH}$ from the hypothalamus, but direct stimulatory action on basal L $\mathrm{H}$ \& FSH in vitro in the pituitary. ${ }^{(28)}$

Fernandez et al. ${ }^{(25)}$ indicated that marked impairment in gonadal function and fertility in the ob/ob mice can be reversed when crossed with ghrelin Ko mice, imply the major role of ghrelin in gonadal function. ${ }^{(29)}$

It is clear from the present work that testosterone supplementation in Gp II and Gp IV produces significant increase in IGF-I (table 1\& fig 6).

These results were in agreement with the previous reports Thomas et al. $^{\text {(30) who reported that supra- }}$ physiological testosterone concentration augment GH and IGF-1 production in elderly male. ${ }^{(30)}$

In animals pulsatile $\mathrm{GH}$ secretion is controlled jointly via feed forward by $\mathrm{GH}$ releasing hormone and ghrelin (a $\mathrm{GH}$ releasing peptide), Low et al. ${ }^{(8)}$ reported that the hypothalamopituitary mechanism by which testosterone promotes $\mathrm{GH}$ secretion and therapy elevates IGF-1 in animals could be due to that hormone. ${ }^{(8)}$ In this work the elevated ghrelin level after testosterone supplementation (table1 \& fig 6) could be one of the mechanisms to increase IGF-1 via increasing level of $\mathrm{GH} .{ }^{(31)}$

We can conclude that plasma ghrelin level significantly increase after testosterone supplementation in 
both sham operated and orchiectomy rats, also there are +ve correlations between ghrelin level and testosterone level (both total and free), IGF-1 and body weight \& negative correlation between ghrelin and FSH \& L H.

\section{REFERENCES}

1. Kojima M, Hosoda $H$, Date $Y$, Nakazato $M$, Matsuo $H$, Kangawa K. Ghrelin is a growthhormone-releasing acylated peptide from stomach. Nature. 1999, 9;402 (6762):656-660.

2. Kojima M, Hosoda H, Matsuo $H$, Kangawa K. Ghrelin: Discovery of the natural endogenous ligand for the growth hormone secretagogue receptor. Trends Endocrinol Metab. 2001;12 (3):118-122.

3. Kletter GB, Cemeroglu AP, Toster CM, Frayo RS, Cumming DE: Serum Ghrelin concentrations after an overnight fasting children and adolescent Across section study. Program of the 84th Annual meeting of the endocrine society, san Francisco, CA (2002), pp 96-97

4. Soriano-Guillén $L$, Barrios $V$, Lechuga-Sancho A, Chowen JA, Argente $\mathbf{J}$ : Response of circulating ghrelin levels to insulin therapy in children with newly diagnosed type 1 diabetes mellitus. Pediatr Res. 2004;55 (5):830-835.

5. Barreiro ML, Gaytan F, Caminos JE, Pinilla L, Casanueva FF, Aguilar E, Dieguez C, Tena-Sempere $M$. Cellular location and hormonal regulation of ghrelin expression in rat testis. Biol Reprod. 2002;67(6):1768-1776.

6. Tena-Sempere M, Barreiro ML, Gonzalez LC, Gaytan F, Zhang FP, Caminos JE, Pinilla L, Casanueva FF, Dieguez $C$, Aguilar E: Novel expression and functional role of ghrelin in rat testis. Endocrinology. 2002; 143 (2):717-725

7. Gaytan F, Barreiro ML, Chopin LK, Herington AC, Morales C, Pinilla L, Casanueva FF, Aguilar E, Dieguez C, TenaSempere M: Immunolocalization of ghrelin and its functional receptor, the type 1a growth hormone secretagogue receptor, in the cyclic human ovary. J Clin Endocrinol Metab. 2003;88 (2):879-887.

8. Low MJ, Otero-Corchon V, Parlow AF, Ramirez JL, Kumar U, Patel YC, Rubinstein $\mathrm{M}$ : Somatostatin is required for masculinization of growth hormone-regulated hepatic gene expression but not of somatic growth. J Clin Invest. 2001;107 (12):1571-1580.

9. Chai JK, Blaha V, Meguid MM, Laviano A, Yang ZJ, Varma M: Use of orchiectomy and testosterone replacement to explore meal number-to-meal size relationship in male rats. Am J Physiol. 1999; 276(5 Pt 2):R13661373

10. Vermeulen A, Verdonck $L$, Kaufman JM: A critical evaluation of simple methods for the estimation of free testosterone in serum. $\mathrm{J}$ Clin Endocrinol Metab. 1999; 84(10):3666-3672. 
11. Shah N, Evans WS, Veldhuis JD: Action of estrogen on pulsatile, nyctohemeral, and enotropic modes of growth hormone secretion. American J of physiology Regulatory, Integrative and Comparative physiology. 1999; (276):R1351R1358.

12. Veldhuis JD, Anderson SM,Kok P, Iranmanesh A, Frystyk J, Orskov H, Keenan DM: Estradiol supplementation modulates growth hormone secretary-burst wave form and recombinant human insulin like growth factor-1 enforced suppression of endogenously driven $\mathrm{GH}$ release in postmenopausal women .J of Clin Endo Meta. 2004; (89): 13121318.

13. Hosoda H, Kojima M, Matsuo H, Kangawa K: Purification and characterization of rat des-Gln14Ghrelin, a second endogenous ligand for the growth hormone secretagogue receptor. J Biol Chem. 2000; 21; 275 (29):2199522000.

14. Svensson AI, Berntsson A, Engel JA, Soderpalm B: Disinhibitory behavior and GABA(A) receptor function in serotonin-depleted adult male rats are reduced by gonadectomy. Pharmacol Biochem Behav. 2000; 67(3):613-620.

15. Gualillo O, Caminos JE, Kojima M, Kangawa K, Arvat E, Ghigo E, Casanueva FF, Dieguez C. Gender and gonadal influences on ghrelin mRNA levels in rat stomach. Eur J Endocrinol. 2001; 144(6):687-690.
16. Tena-Sempere M. Ghrelin: novel regulator of gonadal function. J Endocrinol Invest. 2005;28(5 Suppl):26-29.

17. Pagotto U, Gambineri A, Pelusi C, Genghini S, Cacciari M, Otto B, Castañeda T, Tschöp $M$, Pasquali R: Testosterone replacement therapy restores normal ghrelin in hypogonadal men. J Clin Endocrinol Metab. 2003;88 (9):4139-414331.

18. Ishikawa $T$, Fujioka $H$, Ishimura T, Takenaka A, Fujisawa M: Ghrelin expression in human testis and serum testosterone level. J Androl. 2007;28(2):320-324.

19. Lebenthal Y, Gat-Yablonski G, Shtaif B, Padoa A, Phillip M, Lazar L: Effect of sex hormone administration on circulating ghrelin levels in peripubertal children. J Clin Endocrinol Metab. 2006; 91 (1):328-331.

20. Gambineri A, Pagotto U, De Lasio R, Meriggiola MC, Costantino A, Patton L, Pelusi C, Pelusi G, Pasquali R: Shortterm modification of sex hormones is associated with changes in ghrelin circulating levels in healthy normal-weight men. J Endocrinol Invest. 2005;28(3):241-246.

21. Jockenhövel F, Blum WF, Vogel E, Englaro P, Müller-Wieland D, Reinwein D, Rascher W, Krone W. Testosterone substitution normalizes elevated serum leptin levels in hypogonadal men. J Clin Endocrinol Metab. 1997;82 (8):2510-2513. 
22. Blouin K, Richard C, Brochu G, Hould FS, Lebel S, Marceau S, Biron S, Luu-The V, Tchernof A: Androgen inactivation and steroid-converting enzyme expression in abdominal adipose tissue in men. $\mathrm{J}$ Endocrinol. 2006;191(3):637-149.

23. Broglio F, Benso A, Gottero C, Prodam F, Grottoli S, Tassone F, Maccario M, Casanueva FF, Dieguez C, Deghenghi R, Ghigo E, Arvat E: Effects of glucose, free fatty acids or arginine load on the GH-releasing activity of ghrelin in humans. Clin Endocrinol (Oxf). 2002; 57(2):265-271.

24. Beck B, Musse N, StrickerKrongrad A: Ghrelin, macronutrient intake and dietary preferences in long-evans rats. Biochem Biophys Res Commun. 2002; 12; 292(4):1031-1035.

25. Fernandez-Fernandez R, TenaSempere M, Aguilar E, Pinilla L: Ghrelin effects on gonadotropin secretion in male and female rats. Neurosci Lett. 2004; 20;362(2):103-107.

26. Zigman JM, Elmquist JK. Minireview: From anorexia to obesity--the yin and yang of body weight control. Endocrinology. 2003; 144(9):3749-3756.

27. Furuta M, Funabashi T, Kimura F: Intracerebroventricular administration of ghrelin rapidly suppresses pulsatile luteinizing hormone secretion in ovariectomized rats. Biochem Biophys Res Commun. 2001; 9; 288(4):780-785.

28. Martini AC, FernandezFernandez R, Tovar S, Navarro VM, Vigo E, Vazquez MJ, Davies JS, Thompson NM, Aguilar E, Pinilla L, Wells T, Dieguez C, Tena-Sempere M: Comparative analysis of the effects of ghrelin and unacylated ghrelin on luteinizing hormone secretion in male rats. Endocrinology. 2006; 147(5): 2374-2382.

29. Fernandez-Fernandez R, TenaSempere M, Navarro VM, Barreiro ML, Castellano JM, Aguilar E, Pinilla L: Effects of ghrelin upon gonadotropinreleasing hormone and gonadotropin secretion in adult female rats: in vivo and in vitro studies. Neuroendocrinology. 2005;82; (5-6):245-255.

30. Thomas M, Clifford J, Rosen $\mathbf{S}$ Mitchell H, Katherine M Carotst. C, John DS, Marc RB: Effect of GH and/ or sex steroids on circulating IGF-1 and GFB ps in healthy aged women and men. Am J Physiol. Endcrinol Metab, 2006, 290: E 1006-E1013?

31. Bowers CT: New insight into the control of growth hormone secretion in central and peripheral mechanisms in pituitary, Eds DL Kleinberg \& DR Clemmons. Bristol: Bioscientifica, 2002, pp163-175. 


\title{
دراسة دور التستوستيرون على هرمون الجيرلين قبل وبعد

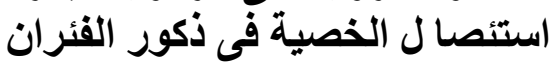

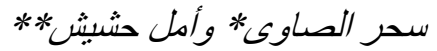

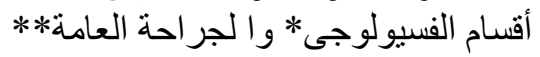 \\ كلية الطب-جامعة طنطا
}

الهذف من هذه الدراسة هو بحث دور التستوستيرون على هرمون الجيرلين قبل وبعد استئصسال

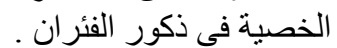

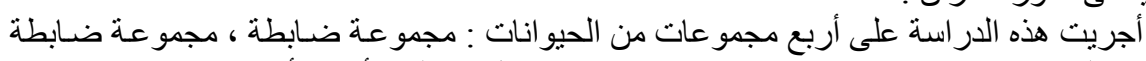

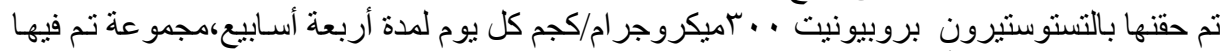

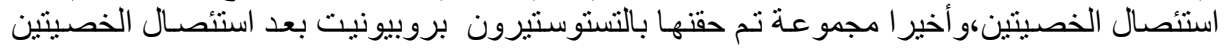

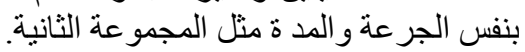

في نهاية ددة البحث تم أخذ عينات الدم لتحليل الهرمونات وتم أيضـا وزن جميع الحيو انات التىى

استخدمت في الدراسة.

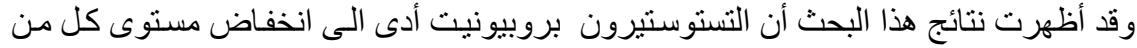
FSH LH\&

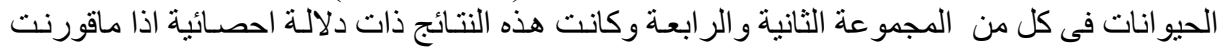

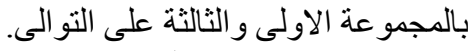

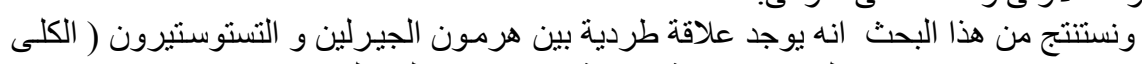

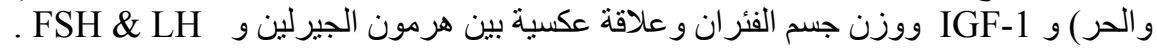

